\title{
MENANGGULANGI CYBERBULLYING DI SOSIAL MEDIA DALAM PERSPEKTIF ANALISA EKONOMI MIKRO
}

\author{
Seno Wibowo Gumbira*1, Adi Sulistiyono ${ }^{2}$, Kukuh Tejomurti ${ }^{2}$ \\ ${ }^{1}$ Program Doktor Ilmu Hukum Fakultas Hukum Universitas Sebelas Maret dan Prodi Ilmu \\ Hukum FHISIP Universitas Terbuka \\ ${ }^{2}$ Fakultas Hukum Universitas Sebelas Maret \\ J1. Ir. Sutami No. 36 A, Surakarta, 57126 \\ seno@ecampus.ut.ac.id
}

\begin{abstract}
The purpose of this study is to find out whether the criminal law system of information and electronic transactions in tackling cyberbullying on social media has been effective and efficient because by referring to the principles of maximization, balance and efficiency? This study uses a doctrinal juridical approach. The results of the research explained that Article 27 Jo Article 45 was formulated not through an assessment using a microeconomic analysis approach so that law enforcement was ineffective and inefficient because by referring to the principle of maximization, balance and efficiency and did not reflect the philosophy of the nation and state of Indonesia namely Pancasila.
\end{abstract}

Keywords: Cyberbullying; Social Media; Micro Economic Analysis

\begin{abstract}
Abstrak
Tujuan penelitian ini adalah untuk mengetahui apakah sistem pemidanaan undang-undang informasi dan transaksi elektronik dalam menanggulangi cyberbullying di sosial media telah berjalan efektif dan efisien karena dengan merujuk pada prinsip maksimalisasi, keseimbangan dan efisiensi? Penelitian ini menggunakan pendekatan yuridis doktrinal. Hasil penelitian menjelaskan bahwa Pasal 27 Jo Pasal 45 dirumuskan tidak melalui pengkajian dengan pendekatan analisa ekonomi mikro sehingga penegakan hukumnya tidak efektif dan efisien karena dengan merujuk pada prinsip maksimalisasi, keseimbangan dan efisiensi dan tidak mencerminkan falsafah bangsa dan negara Indonesia yakni Pancasila.
\end{abstract}

Kata Kunci: Cyberbullying; Sosial Media; Analisa Ekonomi Mikro

\section{A. Pendahuluan}

Globalisasi, telah merambah hampir semua ranah kehidupan masyarakat baik itu di bidang ekonomi, politik, ilmu pengetahuan dan teknologi (IPTEK), budaya, pendidikan dan lain-lain.walaupun istilah " Globalisasi " telah menjadi suatu kosakata yang klasik, tetapi suka tidak suka, masyarakat di seluruh pelosok dunia sekarang ini telah hidup dalam suatu habitat yang global, transparan, tanpa batas, saling mengait dan saling bergantungan (interpendence) (Adi Sulistiyono dan Muhammad Rustamaji, 2009). Negara Kesatuan Republik Indonesia sebagai salah satu masyarakat dunia baik secara langsung maupun tidak langsung dalam menghadapi arus perubahan globalisasi yang telah merambah hampir semua ranah bidang kehidupan kehidupan juga telah mempersiapkan pula segala program pembangunan hampir di seluruh sektor kehidupan demi tercapainya negara yang aman, tentram serta sejahtera yang berlandaskan Pancasila. 
Bahwa kolaborasi antara ilmu hukum dengan disiplin ilmu lainnya pada umumnya dan khususnya ilmu ekonomi pada khususnya merupakan hal yang cukup wajar dan bahkan dikatakan perlu karena perkembangan zaman dan keilmuan, hal tersebut juga dinyatakan oleh Satjipto Rahadjo yang menyatakan bahwa hukum tidaklah hidup dalam ruang yang hampa tapi bergerak ke arah perubahan dan perkembangan kemajuan (Satjipto Rahardjo, 2008). Kontribusi analisis ekonomi mikro dapat membantu ilmu hukum menganalisis peristiwa hukum masa sekarang dan dapat memprediksi secara pasti dan terukur mengenai bangunan politik hukum di masa yang datang. Sehingga analisis ekonomi mikro tersebut juga diharapkan dapat mengatasi kelemahan atau menambah kekuatan yang telah dimiliki ilmu hukum dalam menjalankan fungsi dan peranannya memberikan perlindungan dan jaminan kepastian hukum.

Hukum pidana seharusnya bekerja sesuai dengan pendapat yang dikemukakan Becker yang secara spesifik mengemukakan bahwa analisis ekonomi mikro terhadap hukum pidana meliputi: 1) Keseimbangan antara kepastian dan beratnya hukuman; 2) Perbandingan secara ekonomi antara hukuman denda dan hukuman penjara; 3) Aspek ekonomi dari penegakan hukum dan hukum acara; 4) Efek penjeraan dan pencegahan dari hukuman penjara termasuk hukuman mati (Posner, 1985).

Merujuk pada pergerakan dan perkembangan hukum dan ekonomi dengan metode pendekatan tersebut, pengetahuan mengenai analisis ekonomi mikro tentang hukum sangat relevan dan penting bagi ilmu hukum karena analisis hukum akan memperoleh pengetahuan baru, yaitu mempertimbangkan "cost and benefit ratio" dalam pembentukan undang-undang dan penegakan hukum, sehingga hukum tidak bekerja dalam ruangan hampa tanpa ada makna dan manfaatnya bagi kehidupan manusia. Posner menegaskan, "economics is a powerful tool for analyzing a vast range of legal questions"; here economics means rational choice and price theory, combined with the assumption that 'resources tend to gravitate to their most valuable uses if voluntary exchange-market-is permitted"'(Posner, 1973).

Hukum yang salah satu fungsinya menjamin kelancaran proses pembangunan nasional sekaligus mengamankan hasil-hasil yang telah dicapai harus dapat melindungi hak para pemakai jasa internet sekaligus menindak tegas para pelaku Cybercrime (Tejomurti, Hadi, Imanullah, \& Indriyani, 2019). Pada saat ini sangat banyak perbuatan Bullying yang terjadi di sosial media sangat mengkhawatirkan. Melihat dari sifatnya Cybercrime termasuk dalam kategori borderless cryme (kejahatan tanpa batasan ruang dan waktu), sehingga dalam memberantas tindak kejahatan Cybercrime, diperlukan langkah-langkah yang kompleks, terintegrasi serta berkesinambungan dari banyak pihak, tidak hanya tugas penegak hukum semata (Dista Amalia Arifah, 2011).

Formulasi dalam Undang-Undang No 11 Tahun 2008 tentang Informasi dan Transaksi Elektronik (selanjutnya disebut dengan UU ITE 2008) maupun pada Undang-Undang Nomor 19 Tahun 2016 tentang Informasi dan Transaksi Elektronik (selanjutnya disebut dengan UU ITE 2016) dalam menanggulangi perbuatan cyberbullying, telah diatur pada ketentuan norma Pasal 27 ayat 1 sampai dengan 3 tidak mengalami perubahan. Sebagaimana yang diatur dalam UU ITE 2016 yang menyatakan bahwa "Ketentuan Pasal 27 tetap dengan perubahan penjelasan ayat (1), ayat (3), dan ayat (4) sehingga penjelasan Pasal 27 menjadi sebagaimana ditetapkan dalam penjelasan pasal demi pasal UndangUndang ini”.

Apabila dikaji lebih dalam dan dianalisa relevansinya dengan putusan judicial review Mahkamah Konstitusi RI No 50/PUU$\mathrm{VI} / 2008$ mengenai konstitusionalitas ketentuan Pasal 27 ayat 3 UU ITE tersebut memiliki implikasi terhadap penerapannya ataukah tidak? Hal tersebut dikarenakan subtansi antara UU ITE 2008 yang diubah dengan UU ITE 2016 memiliki subtansi 
Pasal 27 sama tetapi hanya diubah pada penjelasan ketentuan Pasal tersebut. Menginggat pada Putusan Judicial Review oleh Mahkamah Konstitusi tersebut menyebutkan bahwa penghinaan dan pencemaran nama baik sebagaimana yang diatur dalam Pasal 27 ayat 3 UU ITE konsep 2008 mengacu pada Pasal 310 KUHP. Hal tersebut tentunya memiliki konsekuensi pada implementasinya. Mengingat dalam perbuatan dan objek pada KUHP konsep 1880 sebagaimana yang dijelaskan pada Memori Van Toelictihting (M.V.T) dikenal perbuatan nyata berwujud dan benda berwujud. Sedangkan dalam ketentuan Pasal 27 ayat 3 UU ITE tersebut berdimensi virtual. Bahwa dua Pasal yakni, Pasal 310 ayat (1) KUHP dan Pasal 27 ayat (3) UU ITE merupakan pasal karet yang tidak menyebutkan pembatasan atau larangan lebih rinci tentang "pencemaran nama baik". Pasal ini sangat terbuka dan merupakan tempat empuk, arena bermain para pakar hukum (Fidelis Harefa, 2015).

Hal tersebut terlihat jelas sejak 2008 hingga saat ini sangat banyak sekali kasuskasus yang berkaitan dengan Cyber Bullying Indonesia. Berdasarkan Relawan Safenet dan data penelitian telah mendokumentasikan hal-hal yang berkaitan dengan kasus UU ITE di Palembang dan Sumatera, Makassar, hingga Jawa. Menurutnya, ada 225 kasus laporan berkaitan UU ITE, namun hanya 177 kasus saja yang terverifikasi. "Dari total 177 laporan UU ITE, sebanyak 144 kasus atau 81,5 persen menjerat pria dan 65 orang atau 18,4 persen dari wanita," ujarnya dalam acara Dialog Dinamika UU ITE Pasca Revisi di Jakarta, Rabu (28/12/2016). Media sosial Facebook adalah tempat yang paling banyak terjadi pelanggaran UU ITE. Rinciannya, 100 kasus $(56,5 \%)$ kasus UU ITE terjadi di Facebook, diikuti dengan Twitter, media online, pesan singkat, YouTube, blog, email, Path, WhatsApp, petisi online, dan lain-lain. Dalam catatan Safenet, 79,3 persen kasus dilaporkan dengan pasal 27 ayat 3. Pasal lain yang dipakai adalah pasal 28 ayat 2 tentang ujaran kebencian (13\%), pasal 27 ayat 1 tentang pornografi $(1,7 \%)$, dan Pasal 29 mengenai ancaman (4\%)(Agustin Setyo Wardani, 2016). Dengan adanya presentasi seperti ini tentunya memiliki potensi terjadinya overload pada lembaga pemasyarakatan, karena banyaknya kasus cyberbullying di sosial media yang semakin lama semakin bertambah pada setiap tahunnya.

Dengan banyaknya kasus cyberbullying tersebut perlulah sekiranya UU ITE Pasal 27 ayat 1 Jo Pasal 45 ayat 3 tersebut dianalisa dengan pendekatan Economic Analysis of Law mengingat hubungan antara hukum dan ekonomi merupakan keilmuan yang menyatu dan saling mengisi. Pembahasan mengenai kaitan ini merupakan kebaharuan penulisan ini, yang juga merupakan state of the art. Hukum selalu dimaknai sebagai regulasi yang memberikan arahan terhadap perilaku manusia, sedangkan ekonomi sebagai disiplin ilmu yang menekankan pada aspek arah kebutuhan bagi prilaku manusia, sehingga segala permasalahan hukum tentunya akan selalu bersentuhan dengan sisi ekonomi manusia, khususnya hukum pidana.

Berdasarkan penjabaran di atas, maka rumusan masalah yang hendak dikaji antara lain apakah sistem pemidanaan undangundang informasi dan transaksi elektronik dalam menanggulangi cyberbullying di sosial media pasca judicial review Mahkamah Konstitusi RI telah berjalan efektif dan efisien karena dengan merujuk pada prinsip maksimalisasi, keseimbangan dan efisiensi serta apa saja implikasinya baik negara maupun pelakunya? Dengan demikian hal yang hendak dikaji tersebut sangat berkaitan dengan judul artikel ini yakni Implikasi Undang-Undang Informasi dan Transaksi Elektronik dalam Menanggulangi Cyberbullying di Media Sosial.

\section{B. Metode Penelitian}

Penelitian ini menggunakan pendekatan yuridis doktrinal, yakni pendekatan yang memandang hukum sebagai doktrin atau seperangkat aturan yang bersifat normatif. 
Pendekatan ini dilakukan melalui upaya pengkajian atau penelitian hukum kepustakaan. Dalam hal ini penulis menganalisis asas-asas hukum, normanorma hukum, dan pendapat sarjana atau para ahli hukum.

Data yang digunakan dalam penelitian ini adalah data sekunder berupa dokumen, buku, karya ilmiah dan makalah, majalah jurnal dan lainnya. Setelah data sekunder tersebut terkumpul selanjutnya dianalisis secara kualitatif untuk menganalisis dan menjawab permasalahannya.

\section{Hasil dan Pembahasan}

1. Menanggulangi Cyberbullying di Sosial Media dalam Perspektif Analisa Ekonomi Mikro

Ketentuan UU ITE dapat terapkan sesuai kepentingan tertentu dan penerapannya pun bisa keliru terlebih lagi kekuasaan dan tergantung pada diskresi dari penegak hukum begitu dominan. Sebagai contoh pada seperti kenyataannya tanpa belum ada aduan dari pihak yang dirugikan atau dihina melalui media sosial juga dapat dilakukan penangkapan dan penahanan terlebih dahulu. Hal tersebut terlihat pada kasus penghinaan terhadap Kapolri. Dengan kronologi sebagai berikut (Tempo, 2017):

"Tim Cyber Crime Direktorat Reserse Kriminal Khusus Kepolisian Daerah Jawa Timur menangkap warga Bangkalan, Madura, berinisial MS, 24 tahun. Penangkapan itu terkait dengan dugaan penghinaan yang dilakukan MS terhadap Kapolri Tito Karnavian di instagram milik Divisi Humas Polri.Polisi mengancam MS dengan Pasal 27 ayat (3) jo Pasal 45 ayat (3) Undang-Undang Nomor 19 Tahun 2016 tentang Informasi dan Transaksi Elektronik (UU ITE) dengan ancaman 4 tahun penjara dan denda maksimal $\mathrm{Rp}$ 750 juta. "Kami menunggu Divisi Humas Polri melakukan pengaduan, kata Kepala Bidang Hubungan Masyarakat Polda Jawa Timur"
Memperhatikan kasus tersebut diatas, terdapat kekeliruan dalam penerapan Pasal 27 ayat (3) UU ITE 2016 tersebut. Hal ini berbeda dengan ketentuan yang seharusnya terdapat dalam konsep UU ITE 2016 yang mana pada pasal tersebut merupakan delik aduan, sebagaimana judicial review Mahkamah Konstitusi RI dengan Nomor 31/PUU-XIII/2015 juga merupakan delik aduan yang mana prosesnya memerlukan aduan terlebih dahulu. Sehingga penerapannya pun tidak sebagaimana mestinya. Keberhasilan hukum untuk mencapai tujuannya selain dari formulasi undang-undang juga pada pemahaman hukum dan integritas penegak hukumnya. Sebagaimana yang dikemukakan oleh Lon Fuller yakni menyatakan "I have insisted that law be viewed as purposeful enterprise, dependent for uts success on the energy, insight, intelligence and consciousness of those who conduct it" (secara tegas saya melihat hukum sebagai sesuatu upaya dengan maksud tertentu, keberhasilannya tergantung pada energi, wawasan, intelegensia, dan sesadaran dari para pelaku hukum) (Satjipto Raharjo, 1986).

Bahwa penggunaan ketentuan Pasal 27 ayat 3 UU ITE 2016 tersebut paling besar jumlahnya yakni $49,72 \%$ pada tahun pertengahan 2018 dan data tersebut bisa saja berubah dan bertambah. Bahwa formulasi pada Pasal 27 ayat 3 dan beserta sanksinya yang terdapat dalam Pasal 45 ayat 3 baik dalam UU ITE 2008 maupun UU ITE 2016 lebih menitikberatkan kepada pemikiran kantianisme atau retributif semata yang lebih mengutamakan pemidanaaan penjara. Pemikiran kantianisme banyak sekali kekuarangannya, sebagaimana yang dikemukakan oleh Romli Atmasasmita menyatakan bahwa hampir tidak ada kata jera dalam dunia kriminal, sedangkan kejahatan dari bentuk konvensional sampai kepada bentuk yang paling canggih tetap meningkat dengan intensitas yang tinggi.

Perspektif kantianisme yang untuk sementara diperhalus di dalam Lembaga Pemasyarakatan dengan konsep pemasyarakatan, juga tidak menghentikan 
aspek penjeraan. Sebaliknya Lembaga Pemasyarakatan kini ditenggarai sebagai tempat indekost dengan segudang penyakit sosial serta yang terakhir menjadi sarang narkoba (Romli Atmasasmita dan Kodrat Wibowo, 2016). Mengingat formulasi pada rumusan ancaman pidana yang terdapat dalam ketentuan Pasal 45 ayat 3 UU ITE 2016 yakni penjara paling lama 4 (empat) tahun dan/atau denda paling banyak Rp750.000.000,00 (tujuh ratus lima puluh juta rupiah)".

Bahwa berdasarkan APBN Tahun 2012/2013, biaya perkara untuk pemeriksaan perkara tindak pidana di Kejaksaan saja telah dialokasikan sebesar Rp. 250.000.000,- (dua ratus lima puluh juta rupiah). Sedangkan biaya operasional menjalani pidana di lembaga pemasyarakatan dapat diestimasikan perhitungan dimulai biaya makanan narapidana dan tahanan yang jumlahnya secara rata-rata 100.000 orang per tahun, dengan harga satuan BAMA (Lauk pauk dan beras) untuk satu narapidana rata-rata per hari adalah Rp. 15.000,- (lima belas ribu rupiah), sehingga total biaya BAMA dari APBN adalah $(100.000 \times$ Rp. 15.000) $=$ Rp. 15.000.000.000,- (lima belas miliar rupiah).

Jika rata-rata narapidana dijatuhi hukuman 3-5 tahun (tanpa remisi dan bebas bersyarat) maka total biaya negara untuk BAMA dan lain-lain adalah $\mathrm{Rp}$ 16.425.000.000.000,- (enam belas triliun empat ratus dua puluh lima miliar) untuk hukuman penjara 3 (tiga) tahun, dan meningkat sebesar, Rp. 27.375.000.000.000.- (dua puluh tujuh triliun tiga ratus tujuh puluh lima miliar) untuk hukuman penjara selama 5(lima) tahun (Kementerian Hukum Dan Hak Asasi Manusia, 2014).

Berdasarkan hal-hal yang telah dijabarkan diatas, apabila dianalisis dengan menggunakan prinsip-prinsip analisa keekonomian tentang hukum terhadap regulasi dan ketentuan hukum UU ITE di
Indonesia. Karena perangkat analisa keekonomian hukum diproyeksikan menjadi filter keekonomisan guna mengevaluasi, mengestimasi sifat dasar, kemampuan dan kualitas regulasi ketentuan hukum, sehingga dapat memprediksi ketentuan hukum seperti apa dan bagaimanakah yang patut diberlakukan. Adapun hal tersebut digunakan dengan menggunakan prinsipprinsip analisa keekonomian tentang hukum yakni sebagai berikut (Fajar Sugianto, 2014):

Prinsip Equilibrium Composition ini menekankan pada adanya kesenjangan rasionalitas terhadap definisi, persepsi kepentingan dan tujuan pada dasarnya terbagi menjadi dua kiteria yaitu kepentingan rakyat dan kepentingan negara. Sering kali regulasi dan ketentuan hukum yang disusun dan yang diundangkan terdapat kesenjangan rasionalitas yang berawal dari perbedaan definisi (antara suara rakyat dengan para elite), sehingga perberlakuannya tidak efesien dan tidak memiliki kontinuasi. Karena banyak regulasi menjadi tidak efektif dikarenakan tidak diketemukan secara ekplisit yang dapat dijadikan sumber hukum. Definisi tersebut adalah mengenai hal persepsi apakah ada persamaan persepsi antara kepentingan negara memberlakukan suatu UU? Apa saja prioritas negara yang ingin dicapai melalui produk hukum? Sedangkan pada kepentingan rakyat/masyarakat apakah kepentingan rakyat itu? Apa sajakah kebutuhan rakyat itu. Dengan hal tersebut sehingga dapat mempertemukan keseimbangan komposisi (Equilibrium Composition) kepentingan dan tujuan bersama (Fajar Sugianto, 2014). Dengan demikian terlebih dahulu melihat kepentingan atau tujuan negara dalam membuat dan memberlakukan UU ITE pada konsep UU ITE 2008 dan konsep UU ITE 2016 yang terdapat dalam pertimbangannya adalah: 
Tabel 1.

Perbandingan Tujuan Dibentuknya Undang-Undang ITE 2008 dan 2016

Tujuan dibentuknya UU ITE 2008

Dibentuknya pengaturan mengenai pengelolaan Informasi dan Transaksi Elektronik di tingkat nasional sehingga pembangunan Teknologi Informasi dapat dilakukan secara optimal, merata, dan menyebar ke seluruh lapisan masyarakat guna mencerdaskan kehidupan bangsa;
Tujuan dibentuknya UU ITE 2016

Menjamin 4 pengakuan
penghormatan atas hak dan kebebasan
orang lain dan untuk memenuhi
tuntutan yang adil resuai
dengan pertimbangan keamanan
dan ketertiban umum dalam
suatu masyarakat yang demokratis
perlu dilakukan perubahan terhadap
Undang-Undang Nomor 11 Tahun
2008 tentang Informasi ran
Transaksi Elektronik agar terwujud
keadilan, ketertiban umum, dan
kepastian hukum

Untuk menjaga, memelihara, dan memperkukuh persatuan dan kesatuan nasional berdasarkan Peraturan Perundang-undangan demi kepentingan nasional;

Pemanfaatan Teknologi Informasi berperan penting dalam perdagangan dan pertumbuhan perekonomian nasional untuk mewujudkan kesejahteraan masyarakat;

Pengembangan Teknologi Informasi melalui infrastruktur hukum dan pengaturannya sehingga pemanfaatan Teknologi Informasi dilakukan secara aman untuk mencegah penyalahgunaannya dengan memperhatikan nilai-nilai agama dan sosial budaya masyarakat Indonesia.
Berdasarkan kepentingan negara dalam menegakan hukum untuk mewujudkan tujuan-tujuan sebagaimana yang terdapat dalam pertimbangan UU ITE konsep 2008 maupun 2016, akan tetapi pada praktiknya lebih cenderung kepemidanaan, hal tersebut sebagaimana dilihat dari berbagai kasus dan penerapan hukum UU ITE cenderung pada pemidanaan yang represif (kantianisme) penggunaannya dibandingkan tujuan-tujuan sebagaimana dalam konsideran baik UU ITE konsep 2008 maupun konsep 2016. Sebagai contoh banyaknya penyelesaian kasus-kasus yang tidak adil dan jauh dari tujuan dibentuknya kedua UU ITE tersebut dan tingginya tingkat pemidanaan dan penyelesaian jauh dari rasa keadilan di masyarakat sebagaimana data yang 
sebelumnya dipaparkan. Dengan demikian dapat dikatakan bahwa terdapat ketidakseimbangan komposisi (Equilibrium Composition) kepentingan dan tujuan bersama antara negara dengan rakyat. Rakyat merasa asing dengan pemberlakukan dan penerapan UU ITE tersebut.

Pada prinsip Gap-Filling ini ditekankan kepada peran serta aparat penegak hukum dan para pengguna hukum di dalam merealisasikan, menggunakan, dan menerapkan ketentuan hukum itu sendiri. Dengan sendirinya, produk hukum yang efesien mampu memuat semua ketentuanketentuan hukum yang secara ekplisit, mudah dipahami dan mudah diakses. Ekplisit dalam memuat ketentuan, pembolehan, dan pengecualiannya. Dengan kata lain produk hukum harus dapat dijadikan rule of law, bukan lagi dibangun dan dimengerti berdasarkan intepretasiintepretasi (rule of interpretation), namun berdasarkan pemahaman dan pengertian yang konkrit terhadap subtansi pengaturannya (Fajar Sugianto, 2014).

Dengan melihat penerapan UU ITE di Indonesia, terdapat penerapan yang berdasarkan intepretasi diskresi kebijakan aparatur penegak hukum, hal tersebut terlihat bahwa penerapan Pasal 27 ayat $3 \mathrm{Jo}$ Pasal 45 ayat 3 UU ITE tersebut berbeda antara subtansi dengan penerapannya. Pada subtansi konsep UU ITE 2016 proses penegakan hukumnya dapat dilakukan jika ada aduan terhadap korban, sedangkan pada praksisnya tanpa adanya pengaduan dari korban langsung diproses. Sebagaimana telah dikemukakan oleh penulis sebelumnya. Dengan penegakan hukum yang demikian sebagai salah satu contoh penerapan hukum yang rule of interpretation yang merupakan pembenaran praktik-praktik diskresi yang tidak berdasar, seolah-olah hukum selalu memberikan pengecualian atau pembolehan terhadap tindakan penyimpangan hukum, padahal subtansinya tidaklah demikian. Praktik yang demikian mengakibatkan kebingungan publik yang pada akhirnya hukum memiliki nilai instrumental yang berarti regulasi dan ketentuan hukum tersebut merupakan sarana belaka, padahal dalam sudut ekonomi seharusnya regulasi/hukum secara intrinsik bernilai dalam membenarkan dan menjaga konsistensi penegakan hukumnya.

Pada prinsip Hypothetical Bargains ini ditekankan kepada daya guna menghasilkan benefit ketentuan hukum yang dijadikan alat dukung sesuai dengan susbtansinya. Apabila tidak berdaya guna dan tidak menghasilkan benefit (manfaat, kelebihan, perolehan, perbaikan) bagi para pihak, maka dengan sendirinya penggunaan pengaturan hukum ini akan menjadi statik sehingga menjadikannya tidak dinamis (Fajar Sugianto, 2014). Sekalipun produk hukum yang diterbitkan mampu menampung, menunjang, dan memfasilitasi kebutuhan para penggunaanya, kedinamisan ini tidak akan berarti kalau tidak didukung dengan konsistenan dan stabilitas penegakannya (law enforcement).

Jika dianalisa, penggunaan atau penerapan Pasal 27 ayat 3 Jo Pasal 45 ayat 3 UU ITE tidak bahkan kurang menghasilkan benefit. Hal tersebut dikarenakan tindak pidana penghinaan merupakan hal ringan yang dapat diselesaikan dengan musyawarah mufakat tetapi penyelesaiannya lebih mengedepankan retributif pidana pemenjaraan dan penerapannya juga tidak sesuai subtansinya yakni perlunya pengaduan terlebih dahulu tetapi kenyataannya penerapan dapat dilakukan penindakan proses hukum tanpa dan menunggu adanya pengaduan (belum ada pengaduan). Sehingga berdasarkan data di atas dengan banyaknya pemidanaan cyberbullying tersebut tidak memberikan benefit kepada para pihak. Para pihak disini adalah Korban, Pelaku dan juga termasuk negara (aparatur penegak hukum). Bagi korban sendiri belum tentu pemidanaan memulihkan keadaan yang dialaminnya, bagi Pelaku akan kehilangan produktivitasnya khususnya setelah menjalani hukuman, karena akan adanya stigma dari masyarakat sehingga kesulitan mencari kerja dan dapat berpotensi menjadi residivis atau melakukan kejahatan lainnya. 
Bagi negara tentunya akan mengeluarkan biaya operasional penegakan hukum dan beban kerja yang lebih banyak kepada aparatur penegak hukum.

Pada prinsip Correlated Productive ini, ditekankan tingkat produktivitas pengaturan hukum melalui peningkatan kesadaran hukum(legal awareness) kepada seluruh lapisan masyarakat tentang adanya sanksi hukum terhadap tindakan penyimpangan hukum (Fajar Sugianto, 2014). Dalam membangun kesadaran hukum tersebut perlu diawali dengan mempermudah penyampaian pengetahuan dan pemahaman yang tepat terhadap ketentuan hukum, termasuk pada fakta tentang adanya akibat hukum sehingga mencegah keinginan untuk melakukan penyimpangan diikuti dengan penegakan hukum.

Penegakan hukum tidak terletak dalam sanksi hukum, tetapi pemberian hukum merupakan sebagai akibat hukum. Mengenai tingkat kesadaran hukum (legal awareness) di Indonesia perlu dilihat jumlah presentase pelapor dan terlapor serta status perkara mengenai Cyberbullying di sosial media berdasarkan data dari safenet di posisi Juni 2018 adalah sebagai berikut (Gerintya, 2018): (a) Jumlah presentase pada Pelaporan yakni sebanyak 35,92 persen orang yang melaporkan kasus UU ITE adalah pejabat negara, termasuk di dalamnya adalah kepala daerah, kepala instansi/departemen, menteri, dan aparat keamanan. Pelapor awam tercatat mencapai 32,24 persen; (b) Jumlah presentase pada Terlapor yakni sebanyak 29,4 persen terlapor sepanjang periode 2008-2018 tercatat berasal dari kelompok awam itu, Kelompok lain dari terlapor kasus UU ITE yang dapat digarisbawahi adalah aktivis $(8,2 \%)$, pelajar dan mahasiswa $(6,5 \%)$, guru dan dosen $(6,1 \%)$, jurnalis $(5,3 \%)$. Empat latar belakang kelompok terlapor tersebut menjadi tanda bahwa kasus-kasus UU ITE yang selama ini terjadi bersinggungan dengan hak kebebasan berbicara; (c) Jumlah presentase pada status kasus yakni yang dilaporkan berakhir di kepolisian. Jumlahnya mencapai 47,35 persen, 16,73 persen kasus berujung pada vonis bersalah, peluang terlepas dari jeratan UU ITE sangat kecil, persentasenya hanya sebesar 6,12 persen.

Berdasarkan jumlah presentase Pelapor dan Terlapor, serta status kasus pelanggaran UU ITE tersebut dapat disimpulkan bahwa kesadaran hukum masyarakat akan akibat hukum dari pelanggaran UU ITE tersebut cukup tinggi tetapi tetap saja pelanggaran hukumnya selalu terjadi hal ini bisa jadi karena formulasi UU ITE sangat lentur dan terjadinya penerapan penegakan hukumnya sebagaimana yang dijelaskan sebelumnya dilakukan dengan rule of interpretation dan terbukti bahwa bahwa hukum yang represif telah gagal memenuhi cita kepastian, keadilan dan kemanfaatan bagi seluruh rakyat Indonesia sehingga tentunya walaupun adanya kesadaran hukum dari masyarakatnya akan tetapi belum tentu menaati hukum sehingga pelanggaran akan tetap saja terjadi.

Pada prinsip Extensive Ken ini ditekankan kepada ruang lingkup pengetahuan dan pengertian masyarakat secara umum terhadap suatu peraturan baik yang bersifat normatif maupun empiris. Dalam hal ini tentunya juga berkaitan erat dengan prinsip Correlated Productive sebelumnya. Pada jumlah frekuensi Terlapor yang terdiri atas aktivis $(8,2 \%)$, pelajar dan mahasiswa $(6,5 \%)$, guru dan dosen $(6,1 \%)$, jurnalis $(5,3 \%)$. Empat latar belakang kelompok terlapor tersebut menjadi tanda bahwa kasus-kasus UU ITE yang selama ini terjadi bersinggungan dengan hak kebebasan berbicara. Sehingga perlunya adanya pemahaman bahwa kebebasan berbicara yang mana yang dapat diterapkan UU ITE dan mana yang tidak. Karena jika tidak terdapat batasan yang ekplisit dan formulasi yang lex certa atau jelas mana saja kebebasan berpendapat yang dapat digunakan dengan UU ITE dan yang tidak sehingga tidak terjadi overcrimizations yang menyebabkan pemidanaan overblasting (kelampauan beban tugas) dan overcapacity lembaga pemasyarakatan berdampak pada pengeluaran biaya yang tinggi (high cost) oleh negara. 
Bahwa berdasarkan analisa prinsipprinsip Analisa Keekonomian Hukum diatas yang tidak berdiri sendiri dan menjadi satu kesatuan tersebut bahwa UU ITE, khususnya Pasal 27 ayat 3 Jo Pasal 45 ayat 3 tersebut sangatlah tidak mencerminkan prinsip maksimalisasi, keseimbangan dan efisiensi. Sehingga terbukti negara mengeluarkan dana operasional penegakan hukum yang besar dan cenderung keliru penegakannya.

Selanjutnya apabila dikaji dari perspektif sociologial jurisprudence dengan menggunakan teori law as a tool of social engineering yang dikemukakan oleh Rouscoe Pound, maupun dengan teori law as a social control yang dikemukakan oleh E.A Ross adalah pertama, pada teori law as a tool of social engineering bahwa kaidahkaidah hukum secara tegas dan sadar berusaha membawa dan mengarahkan anggota masyarakat untuk membangun berbagai aspek kehidupan menuju masyarakat yang adil dan makmur (Amran Suadi, 2019). Seperti yang diamanahkan oleh GBHN bahwa sasaran bidang pembangunan hukum adalah "terbentuknya dan berfungsinya sistem hukum nasional yang mantab bersumberkan Pancasila dan UUD 1945 yang mampu menjamin kepastian, ketertiban, penegakan dan perlindungan hukum yang berintikan keadilan dan kebenaran serta mampu mengamankan dan mendukung pembangunan nasional"(Amran Suadi, 2019).

Berdasarkan tujuan dibentuknya UU ITE 2008 maupun UU ITE 2016 sebagaimana yang telah penulis jabarkan dalam tabel, yang dianalisa dengan proses penegakan hukumnya dengan terjadinya overcrimizations akibat penegakan hukum yang tidak sesuai kaidahnya seperti belum ada laporan dari yang bersangkutan terjadinya penghinaan di social media (cyberbullying) tetapi karena menyangkut pada suatu jabatan pejabat di Kepolisian RI tetapi telah terlebih dahulu sudah dilakukan tindakan Pro-Yustisia terhadap pelakunya, maka tentunya terjadi tidak tercapainya masyarakat yang adil dan makmur sesuai tujuan hukum yang di cita-citakan tersebut. Karena menggunakan hukum sebagai sarana rekayasa sosial dengan mengeluarkan berbagai peraturan perundang-undangan tanpa dasar berpijak pada nilai-nilai yang dapat disarikan atau diambil dari berbagai putusan hakim yang telah mempunyai kekuatan hukum tetapdan bernilai sebagai jurisprudensi yang merupakan wadah/wahana yang menampung perkembangan nilai-nilai yang ada di masyarakat merupakan tindakan yang sembrono dan tak dapat dipertanggungjawabankan (Djasmani, 1986).

Dalam hal dari perspektif teori law as a social control memberikan arti ia merupakan sesuatu yang dapat menetapkan tingkah laku manusia. Tingkah laku ini didefinisikan sebagai sesuatu yang menyimpang terhadap aturan hukum. Sebagai akibatnya, hukum dapat memberikan sanksi atau tindakan terhadap si pelanggar (Djasmani, 1986). Berdasarkan data sebelumnya. Bahwa diketahui bahwa UU ITE 2008 maupun UU ITE 2016 lebih menitikberatkan pendekatan dengan sanksi yang bersifat represif yang cenderung kantianisme yang berupa pidana penjara ketimbang penyelesaian alternatif lain yang non-kriminal.

Selain diperlukan pendekatan integral, pidana juga memerlukan pendekatan holistik dengan beberapa kriteria sebagaimana yang dikemukakan oleh Sudarto yang terdiri dari 4 (empat) kriteria yang harus diperhatikan dan dipertimbangkan menetapkan proses kriminalisasi yang terutama diantaranya adalah 2 hal yakni pertama Harus diperhatikan cost and benefit principle, artinya usaha untuk mengkriminalisasi harus seimbang dengan hasilnya. Dalam hal ini perlunya perhitungan biaya operasional mulai biaya tahap penyelidikan hingga tahap putusan yang berkekuatan tetap serta biaya lembaga pemasyarakatan bagi pelaku tindak pidana dengan kategori delik ringan yang penyelesaiannya masih dimungkinkan dilakukan di luar litigasi sistem peradilan 
pidana, seperti konsep schikking yang dilakukan oleh Jaksa Agung di Indonesia, yaitu dengan kesepakatan tentang denda damai dalam delik penyelundupan antara terdakwa dan kejaksaan, maka perkara tidak dilanjutkan ke pengadilan (Andi Hamzah, 2012), hal ini dilakukan pertama untuk mempercepat penyelesaian perkara pidana tanpa membebankan keuangan negara dan tercapai keadilan restorative justice antara pelaku cyberbullying dan korbannya.

Kedua, harus dipertimbangkan apakah kriminalisasi menambah beban dari aparat penegak hukum sehingga tidak sampai menimbulkan overblasting (kelampauan beban tugas) sehingga peraturan tersebut kurang efektif (Teguh Prasetyo dan Abdul Hakim Barkatullah, 2005). Agar pemidanaan dan proses penyelesaian cyberbullying tersebut hukum dapat berjalan efektif dan efisien karena dengan merujuk pada prinsip maksimalisasi, keseimbangan dan efisiensi dengan memperhatikan dan mengakomodir cost and benefit principle, serta tercapainya keadilan restorative justice antara pelaku cyberbullying dan korbannya, maka penulis memberikan rekomendasi jenis pidana dan penyelesaian kasus cyberbullying yakni:

Pertama, pemidanaan dengan jenis pidana bersyarat dan pidana denda serta cara penyelesaian dengan mediasi penal sebagai alternatif penyelesaian dan alternatif pemidanaan selain pidana penjara dan denda yang diterapkan terhadap pelaku cyberbullying melalui sosial media harus memenuhi kriteria yakni pelaku masih dibawah umur, apakah residivice atau tidak dalam tindak pidana apapun, pelaku merupakan tulang punggung keluarganya, cyberbullying yang dilakukannya tidak mengakibatkan korban mengalami guncangan psikis dan atau bunuh diri. Hal ini diperlukan guna mencerminkan pemidanaan yang integratif dan humanis yang kemudian pemidanaan juga memperhatikan faktor untuk menyejahterakan dan humanis.

$$
\text { Keutamaan pidana bersyarat }
$$
sebagaimana yang dikemukakan oleh
Muladi, Pertama yakni memberikan kesempatan kepada terpidana untuk memperbaiki diri di masyarakat, sepanjang kesejahteraan terpidana sepanjang kesejahteraan terpidana dalam hal ini dipertimbangkan sebagai hal yang lebih utama dari pada resiko yang mungkin diderita oleh masyarakat seandainya terpidana dilepas di masyarakat. Kedua adalah bahwa pidana bersyarat memungkinkan terpidana untuk melanjutkan kebiasaan-kebiasaan hidupnya sehari-hari sebagai manusia, yang sesuai dengan nilainilai yang ada di masyarakat. Kebiasaankebiasaan ini antara lain adalah melakukan tugas pekerjaannya, melaksanakan kewajiban-kewajibannya di dalam keluarga seperti bekerja. Ketiga adalah bahwa pidana bersyarat akan mencegah terjadinya stigma yang diakibatkan oleh pidana perampasan kemerdekaan (penjara) dan stigma ini seringkali dirasakan juga oleh keluarganya. Keuntungan yang terakhir adalah bahwa secara finansiil maka pidana bersyarat yang merupakan pembinaan diluar lembaga akan lebih murah dibandingkan dengan pembinaan di dalam lembaga (Muladi, 2016).

Bertolak dari pemikiran yang dikemukakan oleh Muladi yang menyatakan bahwa dalam konteks hukum pidana materiil, permasalahan berkisar pada tiga permasalahan pokok hukum pidana yakni perumusan perbuatan yang dilarang (kriminalisasi), pertanggungjawaban pidana (kesalahan) dan sanksi yang diancamkan, baik pidana maupun tindakan (Muladi, 1995). Sehingga dalam hal pemidanaan cyberbullying di sosial media perlulah suatu konsep pemidanaan yang integratif. Hal tersebut dikarenakan dewasa ini masalah pemidanaan menjadi sangat kompleks sebagai akibat dari usaha untuk lebih memperhatikan faktor-faktor yang menyangkut hak asasi manusia, serta menjadikan pidana bersifat operasional dan fungsional.

Pendekatan semacam ini mengakibatkan adanya keharusan untuk memilih teori integratif tentang tujuan 
pemidanaan yang dapat memenuhi fungsinya dalam rangka mengatasi kerusakan-kerusakan yang diakibatkan oleh tindak pidana (individual and social damage) (Muladi, 2016). Salah satu kerusakan berat akibat tindak pidana cyberbullying yakni korban dapat mengalami tekanan secara psikis dan dapat berpotensi bunuh diri. Hal ini terlihat yakni sebagaimana data dari ictwatch.com memberi gambaran dan nyata bahwa pada kasus cyberbully, jauh lebih memprihatinkan. Satu dari 5 anak korban cyberbully berpikir untuk melakukan bunuh diri. Bahkan 1 dari 10 korban cyberbully melakukan tindakan bunuh diri. Dalam setahun, ada sekitar 4500 anak yang mengakhiri nyawanya sendiri (ictwatch.com, 2012).

Kedua, pidana denda dapat dijadikan sebagai alternatif pemidanaan selain pidana penjara agar meminimalisir biaya operasional penegakan hukum. Baik biaya operasional penyidikan sampai lembaga pemasyarakatan. Sebagaimana yang dikemukakan oleh Stephen J. Spur yang membandingkan pidana penjara dengan pidana denda serta memberikan pendapatnya sebagai berikut (Spurr \& Spurr, 2019):

"One punishment that is widely used is imprisonment. The costs of this alternative include not only the cost to the prisoner of being miserable, but also the expense of building and operating prisons, and a loss of productivity of the offender during the period of incarceration." The individual will also less productive after his release, because of his prolonged separation from the labor market and the stigma of conviction of a serious offense. The reduction of his productivity and earning capacity will lower the opportunity cost of crime, and increase likelihood that he will return to crime".
Selain itu dengan memperhatikan pendapat Muladi dan Barda Nawawi Arief, berkaitan dengan kebijakan legislatif yang berhubungan dengan pelaksanaan pidana denda perlu dipertimbangkan mengenai: a) sistem penetapan jumlah atau besaran pidana denda; b) batas waktu pelaksanaan pembayaran denda; c) tindakan-tindakan paksaan yang diharapkan dapat menjamin terlaksananya pembayaran denda dalam hal terpidana tidak dapat membayar dalam batas waktu yang ditetapkan; d) Pelaksanaan pidana denda dalam hal-hal yang khusus (misalnya terhadap anak yang belum dewasa atau belum bekerja dan masih dalam tanggungan orang tuanya); e) pedoman atau kriteria untuk menjatuhkan pidana denda (Muladi dan Barda Nawawi Arief, 2010). Pada penetapan jumlah atau besaran pidana denda kebijakan legislatif harus memperhatikan keadaan pendapatan ekonomi negara dan jumlah rata-rata penghasilan warga negaranya sehingga pelaksanaan pidana denda lebih mudah terlaksana dan menjadi pidana pengganti dari penjara dengan tetap memperhatikan tingkat dampak dari perbuatan cyberbullying tersebut. Hal ini agar tidak terjadi overkapasitas/overload pada lembaga pemasyarakatan, selain itu juga untuk menghindari dampak kriminogen lagi antara pelaku yang pertama kali masuk penjara menjadi mengulangi kembali tindakannya dikarenakannya adanya interaksi dengan pelaku tindak pidana yang residivice, yang dampaknya tidak terpenuhinya tujuan dari pemidanaan tersebut yakni salah satunya adalah membimbing agar terpidana insyaf dan menjadi anggota masyarakat yang berbudi baik dan berguna (Bambang Purnomo, 1993). Maka diperlukanlah pidana baik penjara dan denda berdasarkan kategori berdasarkan jenis delik dan akibat serta ancaman maksimum dan minimum sebagaimana yang terdapat dalam RKUHP konsep 2006/2007 (Barda Nawawi Arief, 2010).

Namun perlu juga menjadi pertimbangan, baik sanksi pidana penjara maupun sanksi pidana denda masih tetap 
berpijak pada pandangan bahwa, "man is a rational-actor-and immoral" yang mampu membuat kalkulasi mengenai keuntungan dan kerugian (cost and benefit analysis) dari kejahatan yang (akan) dilakukannya. Pidana denda hubungannya dengan Pancasila telah diterima dalam sistem pemidanaan melalui tali-temali pada sila-sila Pancasila secara universal. Pemidanaan denda dapat memenuhi tujuan yakni pembebasan, pembinaan menuju masyarakat yang adil dan beradab yang berintegratif dalam kemanusiaan dan sekaligus perlindungan masyarakat dalam sistem Pancasila (J.E Sahetapy, 1982).

Dengan pendekatan ekonomi yang berbasiskan Pancasila demikian sehingga pidana denda dapat menjadi suatu pendapatan negara yang dapat digunakan dalam pembangunan infrastuktur maupun program penjaminan sosial lainnya guna mencapai masyarakat yang sejahtera berdasarkan Pancasila sebagai falsafah negara Indonesia.

Setelah membahas pemidanaan denda, selanjutnya penulis membahas penyelesaaian mediasi penal. Pada konsep penyelesaian mediasi penal pada kasus cyberbullying yang berbasiskan Pancasila sangatlah diperlukan atau urgensi sekali. Sebagaimana diketahui bahwa munculnya mediasi penal dilatarbelakangi oleh 2 (dua) hal. Pertama, mediasi penal muncul dilatar belakangi pemikiran yang dikaitkan dengan ide-ide pembaharuaan hukum pidana (penal reform), yaitu perlindungan korban, ide restoratif justise, ide mengatasi kekakuan dalam sistem yang berlaku, serta ide menghindarkan efek negatif dari sistem peradilan pidana dan sistem pemidanaan yang berlaku saat ini. Kedua, mediasi penal muncul dilatarbelakangi oleh masalah pragmatis, yakni mengurangi stagnasi atau penumpukan perkara dan untuk menyederhanakan proses peradilan (Lasmadi, 2011). Bahwa mediasi penal haruslah mencerminkan volksgeist Indonesia (jiwa bangsa Indonesia) yakni terlaksana dengan mengutamakan musyawarah mencapai mufakat secara kekeluargaan antara pelaku dengan korban cyberbullying dengan win-win solution berdasarkaan kekeluargaan.

Sedangkan melalui pendekatan teori pidana suatu proses penyelesaian agar mencapai restorative justice dengan mengingat apa yang dikemukakan oleh Eddy O.S Hiariej bahwa keadilan restoratif sebagai konsep proses yaitu mempertemukan para pihak yang terlibat dalam sebuah kejahatan untuk mengutarakan penderitaan yang telah mereka alami dan menentukan apa yang harus dilakukan untuk memulihkan keadaan (Eddy O.S Hiariej, 2016). Sehingga aktualisasi atau optimalisasi mediasi penal sebagai wujud konkrit pembaharuan hukum pidana di Indonesia yang tetap berpegang teguh pada Pancasila ini diharapkan mampu mewujudkan keadilan yang subtansial bagi korban. Di sisi lain, mediasi penal juga dapat memberikan efek jera kepada pelaku agar tetap bertanggungjawab serta diharapkan tidak mengulangi tindak pidana agar dapat mewujudkan keadilan hukum dan keadilan sosial yang secara filosofis telah digariskan oleh Pancasila.

\section{Simpulan dan Saran}

Ancaman Pidana UU ITE 2008 maupun 2016 apabila dianalisis dengan pendekatan ekonomi mikro berpotensi menyebabkan biaya penegakan hukum (operasional) menjadi tinggi mulai penyelidikan hingga ke pengadilan dan menyebabkan overload pekerjaan penegak hukum karena banyaknya kasus cyberbullying di sosial media. Selain itu, biaya untuk narapidana dalam penjara menjadi besar terutama biaya penghidupan narapidana kemudian menyebabkan overcapasity lembaga pemasyarakatan dan hilangnya produktivitas narapidana selama periode penahanan; serta stigmanisasi mantan pelaku tindak kejahatan akan mempersulit pelaku untuk mendapatkan pekerjaan dan sehingga dapat berpotensi menjadi pelaku kejahatan lainnya.

Perihal konsep pemidanaan cyberbullying di media sosial pada masa 
mendatang memerlukan pendekatan integral dan pendekatan holistik serta memperhatikan dan mengakomodir cost and benefit principle, sehingga tercapai keadilan restorative justice berdasarkan Pancasila antara pelaku cyberbullying dan korbannya, tidak sampai menimbulkan overblasting pada beban kerja penegak hukum dan overcapasity lembaga pemasyarakatan yang menyebabkan biaya operasional pemidanaan penjara menjadi besar. Konsep yang ditawarkan adalah pidana bersyarat dan mediasi penal dengan syarat yang limitatif dan imperatif.

\section{DAFTAR PUSTAKA}

Adi Sulistiyono dan Muhammad Rustamaji. (2009). Hukum Ekonomi Sebagai Panglima. Sidoarjo: Mas Media Buana Pustaka.

Agustin Setyo Wardani. (2016). Safenet: Pelanggaran UU ITE Terbanyak Terjadi di Facebook. Retrieved April 2, 2019, from

https://www.liputan6.com/tekno/read/2 690352/safenet-pelanggaran-uu-iteterbanyak-terjadi-di-facebook

Amran Suadi. (2019). Sosiologi Hukum Penegakan, Realitas \& Nilai Moralitas Hukum (Edisi Pertama). Jakarta: Kencana.

Andi Hamzah. (2012). Asas-asas Hukum Pidana Di Indonesia \& Perkembangannya. Medan: Soft Media.

Bambang Purnomo. (1993). Asas-Asas Hukum Pidana. Jakarta: Ghalia.

Barda Nawawi Arief. (2010). Bunga Rampai $\begin{array}{lll}\text { Kebijakan } & \text { Hukum } & \text { Pidana } \\ \text { Perkembangan } & \text { Penyusunan } & \text { Konsep } \\ \text { KUHP baru. Jakarta: Kencana. } & \end{array}$

Dista Amalia Arifah. (2011). KASUS CYBERCRIME DI INDONESIA. Jurnal Bisnis Dan Ekonomi (JBE), Volume 18(No. 2) Bulan September 2011), 11.

Djasmani, H. Y. (1986). M Di Indonesia.
Masalah Masalah Hukum, Volumel 40(No 3), 365-374.

Eddy O.S Hiariej. (2016). Prinsip-Prinsip Hukum Pidana. Yogyakarta: Cahaya Atma Pustaka.

Fajar Sugianto. (2014). Economic Analysis Of Law. Serial Analisis Keekonomian Tentang Hukum Seri 1 Pengantar (edisi Revisi). Jakarta: Kencana.

Fidelis Harefa. (2015). Revisi "Pasal Karet" UU ITE? Retrieved April 2, 2019, from Kompasiana.com website: https://www.kompasiana.com/fharefa/5 4f8b6faa333116a158b4792/revisipasal-karet-uu-ite?page $=$ all

Gerintya, S. (2018). Periksa Data Jerat UU ITE Banyak Dipakai oleh Pejabat Negara. Retrieved February 18, 2019, from https://tirto.id/jerat-uu-ite-banyakdipakai-oleh-pejabat-negara-c7sk

ictwatch.com. (2012). 1 dari 10 Korban Cyberbully Lakukan Bunuh Diri! Retrieved from http://ictwatch.com/internetsehat/2012/0 7/11/1-dari-10-korban-cyberbullylakukan-bunuh-diri/

J.E Sahetapy. (1982). Suatu Studi Khusus Ancaman Pidana Mati Terhadap Pembunuhan Berencana. Jakarta: Radjawali.

Kementerian Hukum Dan Hak Asasi Manusia. (2014). Biaya Operasional Lembaga Pemasyarakatan. Jakarta.

Lasmadi, S. (2011). Mediasi Penal Dalam Sistem Peradilan Pidana Indonesia. Inovatif, Volume 4(No 5), 1-10.

Muladi. (1995). Kapita Selekta Sistem Peradilan Pidana. Semarang: Badan Penerbit Universitas Diponegoro.

Muladi. (2016). Lembaga Pidana Bersyarat (revisi). Bandung: Alumni.

Muladi dan Barda Nawawi Arief. (2010). Teori-Teori Dan Kebijakan Pidana. Bandung: Alumni.

Posner, R. A. (1973). Economic analysis of 
law (4th editio). Little Brown and Company.

Posner, R. A. (1985). An Economic Theory of the Criminal Law. Columbia Law Review.

https://doi.org/10.2307/1122392

Romli Atmasasmita dan Kodrat Wibowo. (2016). Analisis Ekonomi Mikro Tentang Hukum Pidana Indonesia (Edisi Pert). Jakarta: Kencana.

Satjipto Rahardjo. (2008). Pemikiran Hukum Progresif (Edisi Pertama). Jakarta: Kompas.

Satjipto Raharjo. (1986). Ilmu Hukum. Bandung: Alumni.

Spurr, S. J., \& Spurr, S. J. (2019). Introduction to the legal system. In Economic Foundations of Law. https://doi.org/10.4324/9781351239783 $-3$
Teguh Prasetyo dan Abdul Hakim Barkatullah. (2005). Politik Hukum Pidana Kajian Kebijakan Kriminalisasi dan Dekriminalisasi. Yogyakarta: Pustaka Pelajar.

Tejomurti, K., Hadi, H., Imanullah, M. N., \& Indriyani, R. (2019). Legal Protection for Urban Online-Transportation-Users' Personal Data Disclosure in the Age of Digital Technology. PADJADJARAN Jurnal Ilmu Hukum (Journal of Law). https://doi.org/10.22304/pjih.v5n3.a5

Tempo. (2017). Hina Kapolri di Medsos, Pemuda Bangkalan Dijerat UU ITE. Retrieved April 2, 2019, from https://nasional.tempo.co/read/879626/h ina-kapolri-di-medsos-pemudabangkalan-dijerat-uu-ite/full\&view=ok 